WellBeing International

WBI Studies Repository

$1-1997$

\title{
Student/Teacher Conflict Regarding Animal Dissection
}

Jonathan Balcombe

The Humane Society of the United States

Follow this and additional works at: https://www.wellbeingintlstudiesrepository.org/acwp_he

Part of the Educational Methods Commons, Humane Education Commons, and the Science and Mathematics Education Commons

\section{Recommended Citation}

Balcombe, J. (1997). Student/teacher conflict regarding animal dissection. The American Biology Teacher, 22-25.

This material is brought to you for free and open access by WellBeing International. It has been accepted for inclusion by an authorized administrator of the WBI Studies Repository. For more information, please contact wbisr-info@wellbeingintl.org.

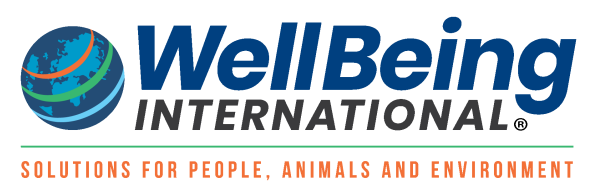




\section{Student/Teacher Conflict Regarding Animal Dissection}

Jonathan Balcombe

The Humane Society of the United States

In 1993, a medical student at the University of Colorado was compelled to transfer to another university when she failed a course for refusing to participate in a required laboratory exercise that involved performing lethal procedures on anesthetized dogs. The student sued and, in August 1995, was awarded $\$ 95,000$ from the university, which promised to establish a review process to accommodate future students who have similar concerns.

Also in 1993, a biology student at the University of Victoria, Canada, studied a live marine mollusk and released it back to the ocean rather than kill and dissect an animal as assigned. She wrote an in-depth report on the mollusk that included anatomical illustrations based on published accounts. In return, she was wrongfully charged with plagiarism for copying the illustrations and given a failing grade. A year later, after a school senate hearing, the plagiarism charge was dropped, but the grade was never adjusted despite repeated appeals to do so.

The foregoing examples are among the more serious of tens of thousands of dissection- or vivisectionrelated conflicts that occur each year in middle schools, high schools and universities throughout North America (Hepner 1994; Francione \& Charlton 1992). The Dissection Hotline (1-800-922-3764), a nonprofit conflict resolution service for students, teachers and parents, has received more than 100,000 calls since its inception in 1989. Four states (New York, Pennsylvania, California and Florida) have enacted laws, and numerous school boards have adopted policies, declaring that students not be forced to dissect animals. These are reminders that there continues to be considerable discontent surrounding dissection (Orlans 1995).

A first step toward resolving conflict is understanding its causes. My aim in this article is to outline some of the misconceptions and misunderstandings that underlie most dissection conflicts. By doing this, I hope to help make the dissection issue less volatile, and one that generates fewer difficulties for students, teachers and administrators.

\section{Why Few Students Object Publicly}

Perhaps the most misunderstood aspect of the animal dissection issue is the number of students who openly object to the practice. Ask a teacher who dissects, and he or she will almost invariably report that unsolicited student objections are rare (Offner 1995), averaging about 3 to $5 \%$ of the class population. In fact, the proportion of students with objections to dissection is much higher. Various surveys in which students were asked about their views on dissection reveal that much higher percentages, in one case $67 \%$, than the assumed 3 to $5 \%$ do object to doing dissections (Table 1 ).

The cause of this discrepancy is simply that the majority of students with an objection never tell their teachers about it. I posit that the main reason for this is that many school teachers and administrators unwittingly foster an atmosphere that is not open to ethical concerns from students regarding dissection. 
In a majority of courses that include dissection, the dissection exercise is presented not as an option but as a required part of the course. Also in a majority of cases, the option to use dissection alternatives, if such an option exists, is not made known to the student. School boards and teachers frequently claim that their students are "offered" dissection alternatives. What this usually means is that while the student may be allowed to use alternatives, he or she is not informed about the choice and must request it. For example, a 1995 survey by the Maryland State Department of Education found that all 24 county school systems "offered" alternatives to students who requested them, but only one county had a written policy mandating that students and/ or their parents be notified of this option. Schools with dissection choice policies that go unannounced can be likened to restaurants that bake apple pies but exclude them from their menus; very few diners will request apple pies.

In the above setting, there appears to be little to encourage, and plenty to discourage students from openly objecting to a dissection exercise. The student faces a number of risks in taking such a stand. These include the possibility of losing grades, ridicule and humiliation in front of one's peers, lost time (e.g. as a result of dropping the course), and feeling compelled to change one's career choice. The average student in this environment will do the required dissection without open complaint, even if it goes against ethical convictions.

Given the risks of requesting an alternative, it is not surprising that so few students go public with their objections to animal dissection. Teachers must realize that a paucity of complaints about dissection does not necessarily represent a lack of objection to it.

Table 1. Published surveys of students' attitudes toward dissection and other animal uses in education.

\begin{tabular}{|c|c|c|}
\hline Author(s) & Study Subjects & Principal Findings \\
\hline Bennett, 1994 & 110 medical students & $\begin{array}{l}78 \% \text { supported student right to opt out of } \\
\text { terminal dog labs. } \\
\text { If given a choice, } 32 \% \text { would not participate in } \\
\text { terminal dog labs }\end{array}$ \\
\hline Bawd, 1993 & 191 Canadian undergraduates & $\begin{array}{l}69 \% \text { were required to perform dissections in } \\
\text { secondary school. } \\
27 \% \text { reported having exclusively negative } \\
\text { reactions to dissection, while } 38 \% \text { reported } \\
\text { both negative and positive reactions. }\end{array}$ \\
\hline Keith-Spiegel et al., 1993 & 482 undergraduates & $\begin{array}{l}62 \% \text { felt that it would be unethical for a } \\
\text { professor to require them to use electric } \\
\text { shock on rats. }\end{array}$ \\
\hline Lord \& Moses, 1994 & 200 undergraduates & $\begin{array}{l}56 \% \text { would object to dissecting an } \\
\text { anesthetized live animal. } \\
48 \% \text { objected to the idea of dissecting a } \\
\text { rabbit, } 56 \% \text { to dissecting a cat, and } 67 \% \text { to } \\
\text { dissecting a monkey. }\end{array}$ \\
\hline Millett \& Lock, 1992 & $\begin{array}{l}468 \text { fourteen- and fifteen-year-old } \\
\text { students }\end{array}$ & $\begin{array}{l}73 \% \text { felt that it is wrong to breed animals for } \\
\text { dissection, } 84 \% \text { felt that alternatives to } \\
\text { animal experimentation should be found, } \\
\text { and } 38 \% \text { "would object to any animal } \\
\text { material being used for dissection." }\end{array}$ \\
\hline
\end{tabular}

\section{Reluctance To Offer Alternatives}

Why are so few students told that they may elect to use an alternative to dissection? Teachers may be concerned that they will lose power to determine course content if students are given a choice. For 
several reasons, that concern is largely unfounded. First, allowing students a choice entails minimal infringement on academic freedom. Teachers are forbidden nothing; they simply add an optional procedure for some students (Shapiro 1988). Second, there is value in providing students a choice in how they pursue an assignment, because doing so encourages students to think for themselves and to take responsibility for their own actions. Conscientious objectors exhibit concern and reflection, qualities to be lauded. Yet, objection to dissection is often viewed as rebellious. Third, choice occurs regularly in the classroom when students are allowed to choose a topic for a science fair project or a subject or medium for an art assignment. If allowing the student a choice is palatable in such cases, it should be no less so for the study of animal anatomy (Downie \& Meadows 1995), provided the alternative learning options are effective (see below).

Table 2. Published studies evaluating the effectiveness of alternatives to dissection and related exercises.

\begin{tabular}{|c|c|c|}
\hline Author(s) & Study Subjects & Principal Findings \\
\hline Dewhurst et al., 1994 & 14 second-year undergraduates & $\begin{array}{l}\text { Six students working independently using a } \\
\text { computer-assisted learning program } \\
\text { achieved equal knowledge gain, at one-fifth } \\
\text { the cost, as did eight supervised students } \\
\text { using freshly killed rats. }\end{array}$ \\
\hline Downie \& Meadows, 1995 & 2,913 first-year biology undergraduates & $\begin{array}{l}\text { Cumulative examination results of } 308 \\
\text { students who studied model rats were the } \\
\text { same as those of } 2,605 \text { students who } \\
\text { performed rat dissections. }\end{array}$ \\
\hline Greenfield et al., 1995 & 36 third-year veterinary students & $\begin{array}{l}\text { Surgical skills were evaluated following } \\
\text { training with dogs and cats, or soft-tissue } \\
\text { organ models; performance of each group } \\
\text { was equivalent. }\end{array}$ \\
\hline Jones et al., 1978 & 100 freshman medical students & $\begin{array}{l}\text { Learning performances of students using } \\
\text { films, computer assisted instruction and } \\
\text { prosected human cadavers were } \\
\text { equivalent to those of students taught using } \\
\text { a traditional lecture-dissection program. }\end{array}$ \\
\hline Samsel et al., 1994 & 110 medical students & $\begin{array}{l}\text { Students used both computer } \\
\text { demonstrations and animal (dog) } \\
\text { demonstrations, and rated the former } \\
\text { higher for learning cardiovascular } \\
\text { physiology. }\end{array}$ \\
\hline
\end{tabular}

Another possible barrier to the adoption of alternatives may be a reluctance to acknowledge that dissection presents an ethical problem. Most secondary and post-secondary teachers agree that raising ethical issues for classroom discussion is a healthy process (Nichols 1995). However, despite the frequency of its use, dissection is rarely broached as an ethical issue by teachers who employ it, despite the benefits of doing so (Orlans 1993; Downie \& Meadows 1995), and at least one dissection expert specifically discourages such discussion (Schrock 1990). The value of including ethical discussions and encouraging critical thinking with students has been affirmed by individuals representing the full spectrum of viewpoints on dissection (Rowan \& Weer 1993). The teacher might best take the role of discussion facilitator and allow students to formulate their own positions on an issue, but he/she should not be surprised by, nor penalize, students who take positions contrary to the establishment view (Rowan \& Weer 1993). 
The cost of alternatives is sometimes used to defend the continuation of animal dissections. The harsh realities of school budgets cannot be taken lightly, but there are at least two valid rejoinders to this argument. First, alternatives need not be expensive. For example, an inexpensive yet highly instructive method for learning animal anatomy is to build a complete model of the animal-insides and outsides-from clay (The Humane Society of the United States (The HSUS), 1995). Second, ordering animal specimens is a significant expense in itself (Kline 1995), and one that must be incurred at least yearly. Unlike dissection specimens, which are used only once then discarded, alternatives can be used repeatedly, giving them a long-term economic edge. Many alternatives are also available as temporary free "previews" from the companies that produce them, or on loan from various animal protection groups (e.g. The HSUS; The National Anti-Vivisection Society; Ethical Science Education Coalition).

\section{Validity of Alternatives}

Perhaps the most common basis of reluctance among biology teachers to offer dissection alternatives is a perception that such alternatives are inferior to dissection. The National Association of Biology Teachers (1995) takes this view in its position statement titled The Use of Animals in Biology Education, which states: "No alternative can substitute for the actual experience of dissection or other use of animals," and "urges teachers to be aware of the limitations of alternatives." Yet, as Sapontzis (1995, p. 184) asks rhetorically: "Has anyone ever done a study showing that factual knowledge gained through alternatives to dissection is incomplete and unappreciated?" On the contrary, there is a considerable and growing body of published evidence indicating that alternatives are at least as good as, and in some cases perhaps better, than dissection for acquiring knowledge of animal anatomy. Table 2 presents a sampling of published studies; a more complete list is available from The HSUS.

Some readers may object that merely "acquiring factual knowledge of animal anatomy" is not what dissection is all about, and that there can be no replacement for the sight, touch and smell of an animal. But they will also know that the rubbery texture, discolored appearance, and powerful chemical odor of animals preserved for weeks or months in formaldehyde doesn't replace the sight, touch and smell of an animal, either. For the teacher who feels that such experiences are indispensable, I recommend taking groups of students to a local veterinary clinic, where they can see the insides of unpreserved, living animals (HSUS). I have found this to be an exciting, eye-opening experience.

What constitutes a viable alternative for students with ethically based objections to dissection? Many students complain that when they raise their objections, their instructors tell them they may watch a dissection without having to do any of the cutting. This is not an acceptable alternative for the conscientious objector, any more than would be attending a rodeo, in lieu of actually performing in it, for someone who opposes rodeos. If the student's objection was based on squeamishness, exemption from having to wield the tools might be helpful. However, in my experience with being consulted by several hundred students not wishing to dissect, I don't know of a single case where squeamishness has been the basis of the objection. Once again, a better grounding in ethics (based on classroom discussion) would help clarify the squeamishness/ethics distinction.

A bonafide dissection alternative is one that will involve no contact, either direct or indirect, with the animals obtained by the school for dissection purposes. The broad diversity of alternatives available to today's teacher and student is illustrated by the Norwegian Inventory of Audiovisuals (NORINA), a database that currently lists more than 3500 alternatives to the use of animals in education (Smith et al. 1994). 


\section{Conclusion}

It is laudable that a majority of biology teachers and policy makers in America today support choice for students regarding dissection. It is a crucial shortcoming, however, that students (and their parents) are routinely not given prior notification of this choice. As Downie and Meadows (1995) demonstrate, there is little to criticize and much to recommend the adoption of openly declared dissection choice policies. Such policies would go far to ease the conflict and tension that currently accompany the dissection issue.

\section{Acknowledgments}

I thank Martin Stephens, Bill DeRosa, Pat Davis, Marilyn Balcombe, Ken Shapiro, Marc Bekoff, Barbara Orlans, and two anonymous reviewers for commenting on earlier drafts of this paper.

\section{References}

Bennett, J. (1994). New survey shows Colorado students want a choice. Good Medicine, 3(3), 6.

Bowd, A.D. (1993). Dissection as an instructional technique in secondary science: Choice and alternatives. Society and Animals, 1(1), 83-88.

Dewhurst, D.G., Hardcastle, J., Hardcastle, P.T. \& Stuart, E. (1994). Comparison of a computer simulation program and a traditional laboratory practical class for teaching the principles of intestinal absorption. American Journal of Physiology, 267 (Advances in Physiology Education, 12(1), S95-S104).

Downie, R. \& Meadows, J. (1995). Experience with a dissection opt-out scheme in university level biology. Journal of Biological Education, 29(3), 187-194.

Francione, G.L. \& Charlton, A.E. (1992). Vivisection and dissection in the classroom: A guide to conscientious objection. Jenkintown, PA: The American Anti-Vivisection Society.

Greenfield, C.L., Johnson, A.L., Schaeffer, D.J. \& Hungerford, L.L. (1995). Comparison of surgical skills of students trained with models or live animals. Journal of the American Veterinary Medical Association, 206(12), 1840-1845.

Hepner, L.A. (1994). Animals in education: The facts, issues and implications. Albuquerque, NM: Richmond Publishers.

Jones, N.A., Olafson, R.P. \& Sutin, J. (1978). Evaluation of a gross anatomy program without dissection. Journal of Medical Education, 53, 198-205.

Keith-Spiegel, P.C., Tabachnick, B.G. \& Allen, M. (1993). Ethics and academia: Students' views of professors' actions. Ethics \& Behavior, 3(2), 149-162.

Kline, A.D. (1995). We should allow dissection of animals. Journal of Agricultural and Environmental Ethics, 8(2), 190-197.

Lord, T. \& Moses, R. (1994). College students' opinions about animal dissections. Journal of College Science Teaching, 23(5), 267-270.

Millett, K. \& Lock, R. (1992). GCSE students' attitudes towards animal use: Some implications for biology I science teachers. Journal of Biological Education, 26(3), 204-208.

Nichols, J.R. (1995). Values and biology education. The American Biology Teacher, 57(5), 268-271.

Offner, S. (1995). Cut here. The Executive Educator, 17, 40.

Orlans, F.B. (1995). Investigator competency and animal experiments: Guidelines for elementary and secondary education. Lab Animal, 24(9), 29-34.

Orlans, F.B. (1993). In the name of science: Issues in responsible animal experimentation. New York, NY: Oxford University Press.

Rowan, AN. \& Weer, J.C. (Eds.) (1993). Biology education and animals: Opportunities and issues (summary proceedings). Tufts Center for Animals and Public Policy, North Grafton, MA. 
Samsel, R.W., Schmidt, G.A., Hall, J.B., Wood, L.D.H., Shroff, S.G. \& Schumacker, P.T. (1994). Cardiovascular physiology teaching: Computer simulations vs. animal demonstrations. Advances in Physiology Education, 11, 536-546.

Sapontzis, S.F. (1995). We should not allow dissection of animals. Journal of Agricultural and Environmental Ethics, 8(2), 181-189.

Schrock, J.R. (1990). Dissection. The Kansas School Naturalist, 36(3), 3-16.

Shapiro, K.J. (1988). Alternatives in education: A philosophical and pedagogical reflection. International Foundation for Ethical Research Newsletter, 2, 3.

Smith, A.J. \& Smith, K. (1996). The NORINA Database of Audiovisual Alternatives. Oslo, Norway: Norwegian College of Veterinary Medicine.

The Humane Society of the United States Youth Education Division. (1995). Alternatives to Dissection (activities packet). Washington, DC: The HSUS. 